\title{
ПРИКАЗИ
}

MA Jovana Marojević

doi: $10.19090 /$ ps.2017.1.78-84

Filozofski fakultet

Nikšić

\section{KA „BOLJEM OD VASPITANJA”}

Graorac, I. (2017). Predškolska pedagogija, Zavod za udžbenike i SAJNOS, Novi Sad, str. 697

Knjiga Predškolska pedagogija, prof. Isidora Graorca objavljena je u oktobru 2017. godine, u izdanju Zavoda za udžbenike i SAJNOS-a. Riječ je o obimnom djelu od 697 stranica, čiji je sastavni dio i CD sa izabranim predavanjima prof. Aleksandre Marjanović. Upravo ta činjenica, između ostalih, čini ovu knjigu dragocjenom stručnoj čitalačkoj publici, naročito onoj mlađe generacije, koja nije imala priliku da neposredno svjedoči snagu i ljepotu pedgoške misli Marjanovićeve. Svi tekstovi okupljeni u ovom zborniku takođe pokazuju sličnu vrstu pedagoškog ubjeđenja - i mada među sobom raznorodni, ovdje ih objedinjuje prije svega nastojanje priređivača i autora, prof. Isidora Graorca, da se učvrsti u sopstvenoj pedagoškoj vjeri, te dai čitaocima vrati vjeru u mogućnosti vaspitanja u 21. vijeku. Neobično je važno što se upravo danas pojavljuje ovakva knjiga, koja po svemu zauzima „posebno“ mjesto u stručnoj literaturi, a koje je sama sebi izabrala - sve u njoj je na određeni način alternativno - autori, teme koje obrađuju, načini na koji im pristupaju, ali je istovremeno sve od fundamenalne naučne i opšte-ljudske važnosti.

U formalnom smislu ovaj zbornik čini devet velikih tematskih cjelina, i to: Djetinjstvo i društvo, roditelji i deca; Pedagoški odnos, ljubav i afektivna vezanost; Dečja igra i stvaralaštvo; Alternativni život i odrastanje dece; Društveno (otvoreno) vaspitanje - mogućnosti zajedničkog življenja dece i odraslih; Školovanje i/ili obrazovanje vaspitača; Prilozi istoriji i koncepciji predškolske pedagogije; Prilozi teoriji obrazovanja; Maternja melodija, crna pedagogija, postpedagogija, i ne/mogućnost obrazovanja. Ovim tematskim poglavljima prethodi segment knjige posvećen pedagoškoj viziji Aleksandre Marjanović, sa autorovim osvrtom na iste, te sa obiljem fragmenata iz njene bogate pedagoške misli. U Predgovoru čitamo neku vrstu direktnog odgovora na ideju Aleksandre Marjanović o društvenom/otvorenom vaspitanju, iz pera Ane Marjanović-Shane; knjiga je zaokružena Rezimeom: saznanja i dileme, u kome prof. Graorac ističe ključne ideje i dileme ovog udžbenika. U njemu su sakupljeni tekstovi preko dvadeset autora, uključujući i tekstove samog priređivača, te značajan 
broj studija prof. Aleksandre Marjanović, čije ideje izvjesno jesu teorijskog uporište i istočnik koncepcije predškolske pedagogijekoja je ovdje predstavljena. Po svojoj prirodi autorski radovi variraju od onih filozofske i antropološke orijentacije koji se bave konstruktom djetinjstva, djetetom, vaspitanjem, koji propituju važna pitanja teorije obrazovanja uopšte, preko onih koji se mogu okarakterisati kao „primjeri dobre prakse“ otvorenog vaspitanja, do tekstova koji tematizuju specifične probleme predškolskog vaspitanja (igra i stvaralaštvo, školovanje i/ili obrazovanje vaspitača, ideje Montesori pedagogije, implicitna pedagogija, otvoreno vaspitanje, komunikacija sa djecom, pedagoška ljubav...), zaključno sa izvorima iz domena crne i postpedagogije, koji čine pedagoško štivo sui generis.

Bez namjere da na ovom mjestu detaljno predstavljamo pojedine priloge koji su se našli u udžbeniku, kratko ćemo se osvrnuti na ključne ideje koje na manje ili više eksplicitan način tematizuju svi tekstovi, a koje možda najbolje odslikavaju i pedagošku viziju samog autora, prof. Graorca, koju nam je posredovao ovim svojim izborima.

\section{Društveno/otvoreno vaspitanje}

Ako sebi dozvolimo slobodniju interpretacju ove knjige možemo zaključiti kako je ona zapravo posvećena imenu Aleksandre Marjanović i njenoj viziji predškolskog vaspitanja. Ne samo da obiluje njenim tekstovima, i da su joj priključeni audio-zapisi predavanja profesorke Marjanović, već se da uvidjeti i kako veliki broj priloga tematizuje jedno od suštinskih pitanja koja je u osnovi pedagoške teorije ove autorke: interesovanje za prevrednovanje i transformaciju društenih odnosa kao osnova za moguće transformacije u vaspitnim odnosima, odnosno vice versa.

U cijelom poglavlju posvećenom fragmentima njene pedagoške teorije, susrećemo se sa i danas unekoliko avangardnom a i alternativnom idejom o društvenom/ otvorenom vaspitanju male djece. Ona sedamdesetih godina XX vijeka govori o ,preobražaju predškolske ustanove u takvu formu društvenog vaspitanja dece koja se konstituiše kroz neposredno učešće dece, vaspitača, roditelja i drugih odraslih u različitim vidovima zajedničkog življenja“ (Marjanović, 1982: 408) i još, kako bi „predškolska ustanova trebalo da se dezinstitucionalizuje i preobrazi u mesto gde bi roditelji mogli na društvenom nivou da upražnjavaju svoj roditeljski poziv" (Marjanović, 1979: 372373). Ova ideja se razmatra podrobno u više tekstova drugih autora u knjizi (I. Graorac, S. Bogojević), a o mogućnostima zajedničkog življenja odraslih i djece raspravlja se i pomalo pesimistički (Mančić, 2013), ali sa druge strane se ukazuje i na ostvarivost ovih idela kroz „zajedničarenje sa roditeljima“ u vrtiću Različak (Marinković, Kovačević, 2015).

Piter Mos (Moss, 2014), pak, 2014. godine, trideset godina kasnije, nudi viziju ranog obrazovanja koja neodoljivo podsjećana pomenutu, Sandinu. Vrtić je zapravo „centar za rano obrazovanje“, organizovan kao višenamjenska ustanova kojoj je samo jedna od funkcija vaspitanje. ,...to je javni prostor ili forum, mjesto susreta među građanima, i odraslima i djecom, i vrsta kolaborativne radionice li laboratorije na korist ovim građanima. Kao takvo, to je mjesto neograničenih potencijala - prostor za mno- 
ge, mnoge projekte i druge mogućnosti. Obrazovanje ... će biti važno. Ali mnogo toga se može dešavati pored obrazovanja ... projekti koji mogu uključivati ko-konstrukciju znanja (učenja)za djecu i odrasle, obezbjeđivanje različitih načina podrške odraslima, posebno roditeljima male djece; izgrađivanje društvene solidarnosti i kohezije zajednice; pomoć da se odupremo dominantnom diskursu, na primjer kroz pedagošku dokumentaciju koja se naknado diskutuje, i da se odupremo drugim formama opresije koje dožive lokalne porodice i zajednice ... doprinos lokalnoj ekonomiji kroz podršku zaposlenin roditeljima i takođe odgovarajuću poslovnu ponudu u okviru samog centra; eksperimentisanje sa novim pedagoškim i projektima zajednice; i promocija rodne i drugih ravnopravnosti“" (Moss, 2014: 90).

Nije li začuđujuća činjenica kako se ideje Aleksandre Marjanović trideset godina ranije poklapaju sa savremenim i naprednim vizijama predškolskog vaspitanja u svijetu (ovdje je naveden samo jedan, eklatanan primjer, ali je takvih mnogo)?! Zato nije neobično što nas priređivač ove knjige vraća njenoj pedagoškoj viziji kao srcu predškolskog vaspitanja, i podsjeća na potrebu preispitivanja i novog čitanja te vizije u duhu postmoderne.

\section{Dijete, djetinjstvo}

Tematika djeteta i djetinjstva u značajnom obimu je obuhvaćena u knjizi, i to ne samo poglavljem koje joj je eksplicitno posvećeno.

Prava je rijetkost naići na pedagoški tekst koji se bavi traganjem za srećom djeteta u pedagogiji, kakvi su tekstovi A. Marjanović (1983) i K. Ručki (1983), od kojih oba na svoj način ustrvrđuju kako sreća u savremenom svijetu nije karakteristika djetinjstva. Danas, pak, mnogo više brinemo o kvalitetu predškolskog obrazovanja kroz visok povraćaj ondosno ekonomsku isplativnost, prema logici Hekmanove krive, nego što smo istinski zainteresovani za radosno življenje djece u vrtiću. Odluka autora da tekstove o sreći djeteta uvrsti u knjigu o predškolskoj pedagogiji danas, osim što svjedoči o njegovom specifičnom pedagoškom senzibilitetu, ujedno predstavlja nedostajući glas o iznimno važnom pitanju predškolske pedagogije, koji se odavno nije čuo.

Među prilozima u zborniku su osim toga ponuđene postpedagoške perspektive djeteta i djetinjstva, iz pera H. fon Šonebeka (2007, 1983/1998, 2006), gdje se prijateljstvo sa djecom odnosno amikacija predlažu umjesto vaspitanja. Šonebek apeluje na odricanje odraslih od slike o djetetu - tek tada može istinski prestati vaspitanje kao misionarenje. Drugačije, ,alternativno“ odrastanje i djetinjstvo dokumentovani su tekstovima samog autora o Porodici bistrih potoka (Graorac, 1995. 1983), gdje vidimo upravo neku vrstu prijateljstva sa djecom na djelu. Govoreći o postmodernom djetetu D. R. Difur (2001/2002) ga opisuje u terminima nekritičke i psihotične jedinke, a N. Milenković (1999) duhovito govori o modelima djeteta, kao o svojevrsnim pedagoškim trendovima ili modama, u odnosu na koje se pedagozi/vaspitači/roditelji ponašaju kao krojači. 


\section{Pedagoški odnos}

Ako se jednim obuhvatnim misaonim pogledom osvrnemo na sadržaj ove knjige kao cjeline, rekli bismo da je ključna sintagma koja predstavlja preokupaciju mnogih tekstova u njoj, pa očigledno i preopkupaciju sastavljača i autora ove zbirke priloga, profesora Graorca: sintagma pedagoškog odnosa, odnosa kao izvora individualnog razvoja, ,jer nesporno je da odnos formira ličnost deteta“ (Graorac, 2017: 156). Ova tematika se razmatra u širokom dijapazonu značenja: od inicijalnih ideja prof. Aleksandre Marjanović o uzdrmanom odnosu ,uzajamnosti odraslih i dece kao osnovnom odnosu“", segregaciji djece, te mogućnostima zajedničkog življenja djece $i$ odraslih (A. Marjanović), preko pitanja pedagoške ljubavi i erosa (G. Ergen) i potrebe za drugim (I. Graorac) do prikaza ideje i nekih uspješnih praksi društvenog/otvorenog vaspitanja (A. Marjanović-Shane), i propitivanja komunikacije u doba postmoderne (H. fon Šonebek).

U udženiku su sabrani i tekstovi kritičke orijentacije, koji problemu pedagoških odnosa pristupaju sa primjesama političnosti (pri čemu se prizivaju uzori poput Freirea), što je takođe u skladu sa idejom o vaspitanju kao političkoj praksi koja je prisutna i kod A. Marjanović, a očigledno i kod Graorca. Difur (2001/2002) govori o školovanju za totalni kapitalizam koji podrazumijeva iskorjenjivanje smisla za kritički odnos prema stvarnostikod djece, kako bi postali dobri potrošači, na koncu, „,dobri Egipćani“ (Gatto, 2005: 14) ili „nemisleći podanici“ (Meklaren, 2013: 359). Grubačić u svom tekstu ističe imperativ revidiranja odnosa moći unutar vaspitno-obrazovnih procesa, koji se zapravo vide kao odnosi eksploatacije (A. Grubačić).

Da li je uopšte moguće stupiti u autenetičan pedagoški odnos danas? Autor ovog zbornika i sebi i nama iznova postavlja to pitanje. Posebno vrijednim smatramo što se u izabranim tekstovima izmješta fenomen pedagoškog odnosa izvan isključivo interakcionih odnosa na ravan društvenih, gdje pedagogijai poprima političnost, i gdje se jedino i može praktikovati kao „slobodarski projekat“, projekat emancipacije, u freireanskom značenju te riječi. Ova knjiga nesumnjivo prenosi poziv A. Marjanović na „promenu shvatanja“, na, rečeno jezikom kritičke pedagogije, u sebi transformativnu i društveno transformišuću pedagogiju (Žiru, 2011, Meklaren, 2013), na, kako Mos ističe, ,pričanje drugačije priče“ u vaspitanju (Moss, 2014: 5), ili uspostavljanje drugačijeg „režima istine“. Od sedamdsetih do danas ovaj apel nije utihnuo, kako nam svjedoče prilozi objedinjeni u Predškolskoj pedagogiji, i vjerujemo da će biti još glasniji, a ova knjiga je svakako snažan doprinos tome.

Nakon ovog kratkog osvrta na sadržaj knjige, imamo potrebu da ukažemo na neke njene specifičnosti.

Budući da Isidor nedvosmisleno i ovim velikim duhovnim poduhvatom i putešestvijem, kakav jeste zbornik koja je pred nama, zastupa, razrađuje, podsjeća i nanovo tumači ideje prof. Aleksandre Marjanović, čini nam se sasvim uputnim „provjeriti““ kvalitet i smisao ove knjige preko kriterijuma koje je sama autorka dala govoreći o „udžbeniku“ predškolske pedagogije. Naime, ,udžbenik ne bi smeo da bude ... zbir praznih iskaza o vaspitanju, koji ponekad mogu da budu i lepo sročene fraze, ali koji 
ništa ne kazuju o vaspitanju kao isečku realnosti i kao delatnosti, pa zato predstavljaju maglovitu apstrakciju, a ujedno i izuzetno dosadno štivo" (1986, 322-323). Ako se pomenuta dva parametra uzmu kao meritorna, onda nesumnjivo možemo ustvrditi da je ovaj prilog predškolskoj pedagogiji izrazito uspješan, budući da izbor tekstova koji su se u njemu našli zaista tematizuju vaspitanje kao dio društvene stvarnosti, u ukupnosti društvenih promjena, svaki iz svoje vremenske perspektive. Kao da se ovim tekstovima zaista nastojalo da se „utiče na formiranje ličnosti studenta“, kako ističe A. Marjanović, te se u tom smislu poduhvat ove knjige i njena primarna namjena studentima (kako sam autor ističe na strani 39) mogu smatrati zaista uspjelim. Upravo ideja o vaspitačkom pozivu kao „pravom ljudskom angažmanu“ (Marjanović) se nedvosmisneno promoviše izborom tekstova u ovom zborniku, što u predominaciji literature koje pedagogiju i vaspitanje svodi na tehniku, zaista predstavlja rijetkost i osvježenje.

Ova knjiga ima potencijal ne samo da podsjeti, već i da probudi, začudi, onespokoji čitaoca, i to na kreativan način, na način koji dovodi do individualnog rasta pojedinca, bilo da je on prosvjetni djelatnik, roditelj, ili samo pojedinac zainteresovan za dijete i djetinjstvo, kao fundamentalne kategorije društva. Razlog ovome ne leži samo u činjenici da su među sabranim tekstovima oni koji na određeni način dovode u pitanje same temelje vaspitanja ili makar predominanti način na koji se teorija i praksa vaspitanja danas manifestuju (tekstovi H. Fon Šonebeka, K. Ručki, A. Grubačića, B. Hamvaša), pa su po svojoj prirodi provokativni, da ne kažemo „uznemirujući“ - već i u izvjesnoj „tenziji“ koja se osjeća u koncepciji ove knjige, a koja čitaoca iz poglavlja u poglavlje najprije napominje na ključne ideje jedne nadasve oljuđene koncepcije predškolskog vaspitanja (čiji izvor nalazimo u pedagoškoj misli Aleksandre Marjanović), ali ga ujedno u nizu tekstova suočava sa onim što su fundamentalni problemi ovog područja ljudskog djelovanja i života, usput mu postavljajući mnogobrojna pitanja, ukazujući kako alternativna rješenja ipak u praksi jesu moguća, a ujedno dajući jedan, u naznakama, nihilistički (ne pesimistički) ton izborom tekstova u završnom poglavlju. Svojevrsna konfrontacija unutar samog teksta ove knjige kao cjeline možda nije izraz predumišljaja autora, ali svakako ima izuzetno poželjan, a nažalost prilično rijedak, učinak čitanja pedagoškog štiva: zapitanost nad fundamentalnom „ne/mogućnošću“ vaspitanja danas.

Predškolska pedagogija zahtijeva aktivan odnos sa tekstom i iznesenim idejama, obavezujući na konstantno promišljanje, i to dvostruko. Formalno gledano, svako poglavlje praćeno je setom otvorenih dilema i problema - Predlozi za razmišljanje $i$ istraživanje - kojima I. Graorac iz meta-pozicije sagledava ključne ideje iznesene u datoj tematskoj cjelini u opšte-društvenom kontekstu, podižući nanovo ključna pitanja, nekad se sučeljavajući sa stavovima pojedinih autora, što ima za cilj stvaranje neke vrste konstruktivnog nespokoja kog čitaoca, kako je i autor ovih redova više puta tokom čitanja knjige iskusio. Osim te formalne ravni, svaki pojedinačni tekst u knjizi u sadržinskom smislu nudi ili razmatra neki specifičan obrt, često zaokret u odnosu na dominantne koncepcije (djeteta, djetinjstva, vaspitanja, odnosa...), što mišljenje čitaoca ne vodi u slijepu ulicu, ali vodi u sumnju i čnđenje. U izabranim tekstovima se zaista očuđavaju fenomeni koje smo skloni da podrazumijevamo, nude se drugačije perspektive za njihovo sagledavanje, pa je za čitanje ove knjige nužan 
preduslov sklonost i spemnost za propitivanje i revidiranje utabanih puteva i načina vaspitanja, kao načina življenja. Suvišno bi bilo govoriti koliko je višestruko korisno biti doveden u situaciju da promišljaš svoj pedagoški kredo, a posebno za one koji su u povoju razvoja svojih pedagoških ličnosti - za studente. Zato ova knjiga predstavlja potencijalno veoma važan izvor u nastavi predškolske pedagogije na univerzitetima, $\mathrm{i}$ kako takvu je i preporučujemo. Neobični potencijal ovog udžebika možda je najbolje izražen riječima jednog od recenzenata knjige, dr Vesne Colić, koja je objašanjava kao svojevrstan ,poziv na avanturu“, jer ovdje zaista nije riječ o bezbijednom pedagoškom putešestviju, već o čitalačkom procesu punom neizvjesnosti, nakon koga zasigurno nećete izaći kao ista (pedagoška) ličnost.

Karakteristično je i posebno dragocjeno stasavajućim generacijama praktičara i teoretičara predškolskog vaspitanja kako prilozi koju su objedinjeni u knjizi pokrivaju višedecenijski raspon, od sedamdesetih godina prošlog vijeka, pa kao takvi, ovi tekstovi mogu biti čitani i kao svojevrsni istorijski pogled na predškolsku pedagogiju ili čak misao o vaspitanju uopšte, iz dominantne pedagoške perspektive samog autora knjige - duboko humanističke, mada postpedagoške, rekli bismo. Čitanje ove knjige u istorijskoj pespektivi zapravo nam svjedoči kako, od sedamdesetih pa do prve decenije novog milenijuma, istinske pregaoce $u$ oblasti predškolske pedagogije (među kojima je i sam prof. Graorac) zaokupljaju ista pitanja, koja su se samo vremenom izoštravala, a koja korijen svog problema i perspektivu razrješenja suštinski vide u istom - uzdrmanim odnosima uzajamnosti između djece i odraslih, za čiju se harmonizaciju i humanizaciju zapravo zalažu, ne gubeći iz vida narušene društvene odnose, utemeljene na potrošačkim osnovama, u kojima i dijete i djetinjstvo i vaspitanje postaju roba. Meta-narativ neoliberalizma natkriljuje sve sfere ljudskog postojanja i stvaralaštva, pa tako ni pitanja vaspitanja nisu ostala pošteđena uspostavljanja novih odnosa na bezmalo ekonomskim osnovama, gdje ,ugovor" postaje obrazac ljudskih veza, kako ističe Bauman (Bauman, 2009: 77).

Iz pozicije vaspitača gledano, pošto je ova knjiga najviše namijenjena oblikovanju njihovih ličnosti, može se reći kako knjiga ne nudi uputstva za „praktikovanje“ vaspitanja (jer se, prije svega, vaspitanje ovdje vidi kao življenje), ali sa druge strane, što je još i važnije, knjiga predstavlja radionicu uma, vježbaonicu uma i srca onih koji se bave predškolskim vaspitanjem teorijski ili praktično. Ovaj zbornik postavlja mnoga zašto pitanja, povremeno uzdrmavajući temelje pedagoške vjere, jer da bismo istinski vjerovali u mogućnosti vaspitanja kao zajedničkog življenja djece i odraslih, u vaspitanje kao slobodarski projekat, projekat kritičke transformacije društva, moramo biti pomalo i utopisti i nihilisti, za šta se i sâm autor ove knjige nesumnjivo opredeljuje: „između „realizma“ i utopijskog mišljenja radije ću se opredeliti za ovo drugo“ (Graorac, Rezime: saznanja i dileme). Graorac ustvrđuje kako u postmodernom vremenu „vaspitanje zapravo nije moguće“. On je u tom smislu postpedagoški mislilac, jer i sam tvrdi kako „traga za nečim što je bolje od vaspitanja“ (Graorac, 148). Nesumnjivo, prilozi u ovoj knjizi predstavljaju tragove koji makar u segmentima polemišu o nečemu „boljem od vaspitanja“.

Ako je to bila namjera autora, u tom se i uspjelo. 


\section{Literatura}

Bauman, Z. (2009). Postmoderna etika, Agom, Zagreb.

Gatto, J. T. (2005). Dumbing Us Down: The Hidden Curriculum of Compulsory Schooling, Gabriona Island: New Society Publisher

Meklrane, P. (2013). Život u školama, Beograd: Eduka.

Moss, Peter (2014). Transformative Change and real Utopias in Early Childhood Education, A story of democracy, experimentation and potentiality, Routledge, London and New York

Žiru, A. (2011). O kritičkj pedagogiji, Beograd: Eduka. 